\title{
Planar Cell Polarity Signaling: The Developing Cell's Compass
}

\author{
Eszter K. Vladar ${ }^{1}$, Dragana Antic ${ }^{1,2}$, and Jeffrey D. Axelrod ${ }^{1}$ \\ ${ }^{1}$ Department of Pathology, Stanford University School of Medicine, 300 Pasteur Drive, Stanford, \\ California 94305 \\ ${ }^{2}$ Department of Developmental Biology, Stanford University School of Medicine, 300 Pasteur Drive, \\ Stanford, California 94305 \\ Correspondence: jaxelrod@stanford.edu
}

Cells of many tissues acquire cellular asymmetry to execute their physiologic functions. The planar cell polarity system, first characterized in Drosophila, is important for many of these events. Studies in Drosophila suggest that an upstream system breaks cellular symmetry by converting tissue gradients to subcellular asymmetry, whereas a downstream system amplifies subcellular asymmetry and communicates polarity between cells. In this review, we discuss apparent similarities and differences in the mechanism that controls PCP as it has been adapted to a broad variety of morphological cellular asymmetries in various organisms.

$\mathrm{T}_{\mathrm{p}}^{\mathrm{h}}$ he terms tissue polarity and planar cell polarity (PCP) were coined to describe the coordinated orientation of cells and cellular structures along an axis within the plane of an epithelial surface. Polarized cellular orientation and migration controlled by PCP is critical for multiple developmental processes, and defects underlie developmental anomalies. Vertebrate PCP mutations produce problems, including neural tube, cardiac, and renal developmental defects and misorientation of hair follicles and inner ear hair cells (Wang and Nathans 2007; Simons and Mlodzik 2008). PCP may be involved in the invasive and metastatic properties of carcinomas (Jessen 2009). Recently, many PCP-related phenotypes have been observed in association with mutations affecting primary cilia, thus connecting primary cilia to the PCP process (Singla and Reiter 2006; see Hirokawa et al. 2009). Therefore, dissecting the mechanisms of PCP signaling is of considerable interest.

PCP was initially characterized in Drosophila through genetic studies of PCP mutants, which led to the proposal of a PCP signaling pathway (Wong and Adler 1993; reviewed in Adler 1992). According to newer models, epithelial polarity is established by the combination of a global directional cue distributed throughout the epithelium and cellular factors that interpret this cue to align cells with each other and the axis of polarity (Tree et al. 2002a; Zallen 2007). Once molecular polarity is determined, cell-type-specific downstream proteins affect morphological polarity. PCP components are highly conserved from flies

Editors: Rong Li and Bruce Bowerman

Additional Perspectives on Symmetry Breaking in Biology available at www.cshperspectives.org

Copyright (C) 2009 Cold Spring Harbor Laboratory Press; all rights reserved; doi: 10.1101/cshperspect.a002964

Cite this article as Cold Spring Harb Perspect Biol 2009;1:a002964 
to vertebrates, and the PCP pathway is now known to be active in many processes in polarized cells and tissues not limited to epithelia. PCP components are involved in oriented cell division, acquisition of asymmetric cellular morphology, and directional cell migration, each process representing a vectorial behavior. Although the mechanism of PCP signaling in most cases is just beginning to be understood, there appear to be diverse mechanisms sharing common themes. This mechanistic diversity may be demanded by the varying PCPdependent morphological processes, and evidently arose by divergence from a common ancestral mechanism.

Here, we describe our current understanding of how the PCP pathway functions in diverse processes, highlighting both common themes and diverging mechanisms. The obvious medical importance of the PCP pathway (see, for example, Kibar et al. 2007), and the growing interest in primary cilia will surely stimulate rapid gains in our knowledge of PCP in multiple cellular contexts.

\section{EPITHELIAL PLANAR CELL POLARITY}

From Dishevelled Flies to a Model for Asymmetric Protein Localization

The pupal wing and the compound eye are the two most thoroughly studied planar polarized tissues in the fly. Each side of the fly wing is a uniform, hexagonally packed epithelial layer in which a single actin-based hair emerges from the distal side of each cell and points distally. The fly eye, a more complex epithelium, is a lattice of repeating units called ommatidia, each containing eight asymmetrically arranged photoreceptor cells. The asymmetric packing of photoreceptor cells imparts chirality, and ommatidia of opposite chirality are found on opposite sides of the equator in the wild-type eye. PCP mutations in the eye can block or reverse the chirality of ommatidia and their subsequent rotation. PCP mutations in the wing cause hairs to lose their distal position, emerging instead from the center of the cell, or from aberrant locations at or near the periphery.
Consequently, proximal-distal orientation and local alignment between neighboring cells is impaired (Fig. 1A). These two structurally and functionally different tissues together have yielded a wealth of information about the PCP mechanism. Additional polarized tissues that have been used to study PCP include the epithelia covering the abdomen and notum (reviewed in Simons and Mlodzik 2008).

A group of evolutionarily conserved genes affecting PCP in all tissues are often referred to as the "core" PCP genes. They are involved in establishing molecular asymmetry within and between cells, and encode Frizzled $(\mathrm{Fz})$ (Vinson et al. 1989), Flamingo (Fmi; aka Starry night) (Chae et al. 1999; Usui et al. 1999), Van Gogh (Vang; aka Strabismus) (Taylor et al. 1998; Wolff and Rubin 1998), Prickle (Pk) (Gubb et al. 1999), Dishevelled (Dsh) (Klingensmith et al. 1989; Theisen et al. 1994), and Diego (Dgo) (Feiguin et al. 2001; Das et al. 2004). (See Table 1 for a summary of Drosophila PCP protein names and vertebrate homologs.) A second group of proteins have been shown by epistasis studies to function downstream of these core proteins (reviewed in Adler 1992; Shulman et al. 1998). Most of these show some tissue specificity, and while less is known about them, a reasonable view is that they couple signaling from the core proteins to the cell-type-specific responses required to generate PCP (reviewed in Adler 1992; Axelrod and McNeill 2002; Tree et al. 2002a).

It has been proposed that the core PCP proteins mediate cell-cell communication. A critical insight into the function of the core PCP proteins was the finding that, before morphological polarization, they adopt polarized subcellular distributions. Fmi was first seen to alter its subcellular localization from a uniform distribution in adherens junctions to a distribution highly enriched at both proximal and distal cell junctions (Usui et al. 1999). Subsequently, the other core PCP proteins were found to adopt unipolar distributions, becoming enriched selectively at either the proximal (Pk, Vang) or distal (Fz, Dsh, Dgo) side of the cell, where they are thought to communicate polarity information between 
A

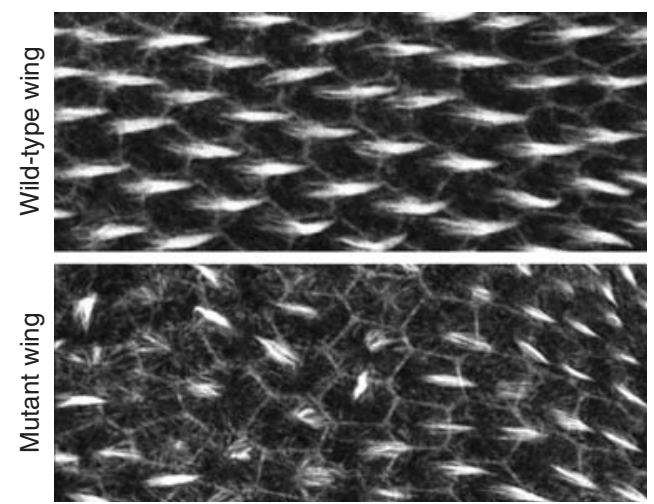

B

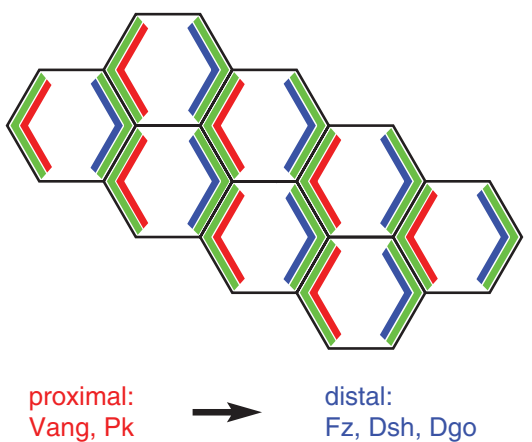

proximal and distal: Fmi

C

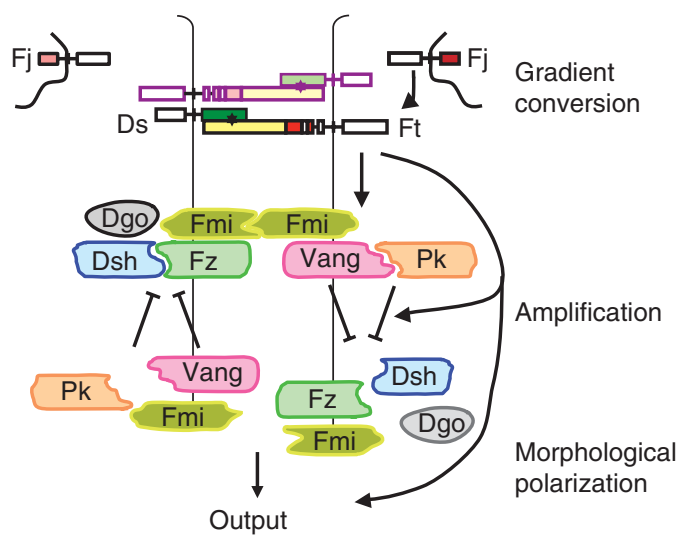

Figure 1. Planar cell polarity in Drosophila. (A) Image of wild type (top panel) and PCP mutant Drosophila pupal wing epithelium, labeled with phalloidin to stain actin. $(B)$ Schematic of PCP protein asymmetric cortical distribution in the fly wing epithelium showing Pk and Vang enriched on the proximal, Fz, Dsh, and Dgo on the distal and Fmi on both proximal and distal sides of each cell. $(C)$ A model for organization of the PCP pathway in Drosophila. Heterodimers of Ft and Ds show biased orientation at each cell boundary, resulting from graded expression of $\mathrm{Fj}$ and Ds. Asymmetrically oriented Ft-Ds heterodimers bias the function of a feedback loop consisting of the core PCP proteins, Fmi, Fz, Dsh, Dgo, Vang, and Pk.

neighboring cells (reviewed in Strutt and Strutt 2005; Zallen 2007) (Fig. 1B).

Although the mechanism leading to this polarized distribution is poorly understood, it depends, at least in part, on directional microtubule-based transport of $\mathrm{Fz}$, together with Dsh and Fmi, to the distal side of the cell (Shimada et al. 2006). Asymmetric cortical recruitment of core PCP complexes also relies on intercellular feedback at the interface of neighboring cells (Tree et al. 2002b; Amonlirdviman et al. 2005) (Fig. 1C). This is mediated by an asymmetric, homotypic interaction between Fmi bound to $\mathrm{Fz}$ in one cell and Fmi associated with Vang in the other (Usui et al. 1999; Shimada et al. 2001; Das et al. 2002; Bastock et al. 2003; Lawrence et al. 2004; Chen et al. 2008; Devenport and Fuchs 2008). Mutual inhibition between Fz/Dsh and Vang/Pk complexes is proposed to drive the system to an asymmetric distribution (Tree et al. 2002b; Amonlirdviman et al. 2005; reviewed in Klein and Mlodzik 2005; Zallen 2007), but this is not yet understood in molecular terms. Feedback may depend on molecular interactions between proximal and distal 
E.K. Vladar, D. Antic, and J.D. Axelrod

Table 1. PCP components in files and vertebrates

\begin{tabular}{|c|c|}
\hline Drosophila & Vertebrates \\
\hline Van Gogh (Vang) & Van Gogh-like 1 (Vangl1) \\
\hline Strabismus $(\text { Stbm })^{1}$ & Van Gogh-like 2 (Vangl2) \\
\hline \multirow[t]{2}{*}{ Prickle (Pk) } & Prickle1 (Pk1) \\
\hline & Prickle1 (Pk2) \\
\hline \multirow[t]{3}{*}{ Frizzled (Fz) } & Frizzled3 (Fz3) \\
\hline & Frizzled6 (Fz6) \\
\hline & Frizzled7 (Fz7) \\
\hline \multirow[t]{3}{*}{ Dishevelled (Dsh) } & Dishevelled1 (Dvl1) \\
\hline & Dishevelled2 (Dvl2) \\
\hline & Dishevelled3 (Dvl3) \\
\hline Flamingo (Fmi) & Celsr1 \\
\hline \multirow[t]{2}{*}{ Starry Night $(\text { Stan })^{1}$} & Celsr2 \\
\hline & Celsr3 \\
\hline Diego (Dgo) & Inversin \\
\hline Fuzzy (Fy) & Fuzzy \\
\hline Inturned (In) & Inturned \\
\hline Rho1 & RhoA \\
\hline \multicolumn{2}{|l|}{ Rho ${ }^{1}$} \\
\hline Drok & Rok/Rock \\
\hline \multirow[t]{4}{*}{ Fat $(\mathrm{Ft})$} & Fat1 \\
\hline & Fat2 \\
\hline & Fat3 \\
\hline & Fat4 \\
\hline \multirow[t]{2}{*}{ Dachsous (Ds) } & Dachsous1 (Dchs1) ${ }^{3}$ \\
\hline & Dachsous2 (Dchs2) ${ }^{3}$ \\
\hline Four-jointed (Fj) & Fjx \\
\hline \multirow[t]{4}{*}{ Wingless $(\mathrm{Wg})^{2}$} & Wnt4 \\
\hline & Wnt5a \\
\hline & Wnt7a \\
\hline & Wnt11 \\
\hline
\end{tabular}

${ }^{1}$ Italicilized text indicates alternative name in Drosophila.

${ }^{2} \mathrm{Wg}$ does not directly regulate PCP in Drosophila.

${ }^{3}$ Role in PCP not determined.

components, as Vang and Pk both bind Dsh and inhibit its membrane recruitment and function (Tree et al. 2002b; Bastock et al. 2003). Dgo also binds Dsh, which promotes its activity and blocks the antagonistic effect of Vang/Pk (Feiguin et al. 2001; Jenny et al. 2003; Das et al. 2004; Jenny et al. 2005). Feedback may also involve regulated vesicle trafficking (Shimada et al. 2006; Strutt and Strutt 2008). The assembly of asymmetric intercellular complexes both communicates polarity information between cells and helps define and stabilize the asymmetric cortical domains within cells (see McCaffrey and Macara 2009; Orlando and Guo 2009).

Communication of polarity information between cells accounts for the observations that $f z$ and vang loss-of-function clones, as well as gain-of-function clones for all of the core PCP proteins, strongly perturb the polarity of nonmutant (or overexpressing) tissue adjacent to the clones, a phenomenon called domineering nonautonomy (Adler et al. 2000; Amonlirdviman et al. 2005). Studies of domineering nonautonomy have been a mainstay of efforts to dissect the functions of the core PCP proteins.

In the wing, the asymmetrically arrayed core PCP proteins provide proximal and distal signals within each cell (Strutt and Warrington 2008) that result in a distal condensation of actin, which forms the single, distally positioned wing hair (Fig. 2). Downstream of core components, these cytoskeletal changes are mediated by tissue-specific PCP effectors. For example, in the wing, the small GTPase RhoA and its associated kinase Drok, known regulators of actin dynamics, contribute to organizing distal actin assembly and prehair formation (Strutt et al. 1997; Winter et al. 2001). The FH3-domain protein Multiple Wing Hairs and the membrane proteins Inturned (In) and Fuzzy (Fy) act cell autonomously on the proximal side and appear to be involved in restricting the site of wing hair initiation (Park et al. 1996; Collier and Gubb 1997; Strutt and Warrington 2008).

PCP core complexes are also found in asymmetric cortical domains in the Drosophila eye. Here, the key intercellular interface is the boundary between the R3 and R4 photoreceptor cells, where $\mathrm{Fz} / \mathrm{Dsh} / \mathrm{Dgo}$ localize to the polar side of R3 and Vang/Pk to the equatorial side of R4 (reviewed in Zallen 2007; Simons and Mlodzik 2008) (Fig. 2). Fmi colocalizes with both complexes and is required in both cells (Das et al. 2002). PCP signaling occurs before photoreceptor cell fate determination by biasing the asymmetry of Notch signaling between the prospective R3 and R4 cells, thereby specifying their fates based on their position relative to the equator 


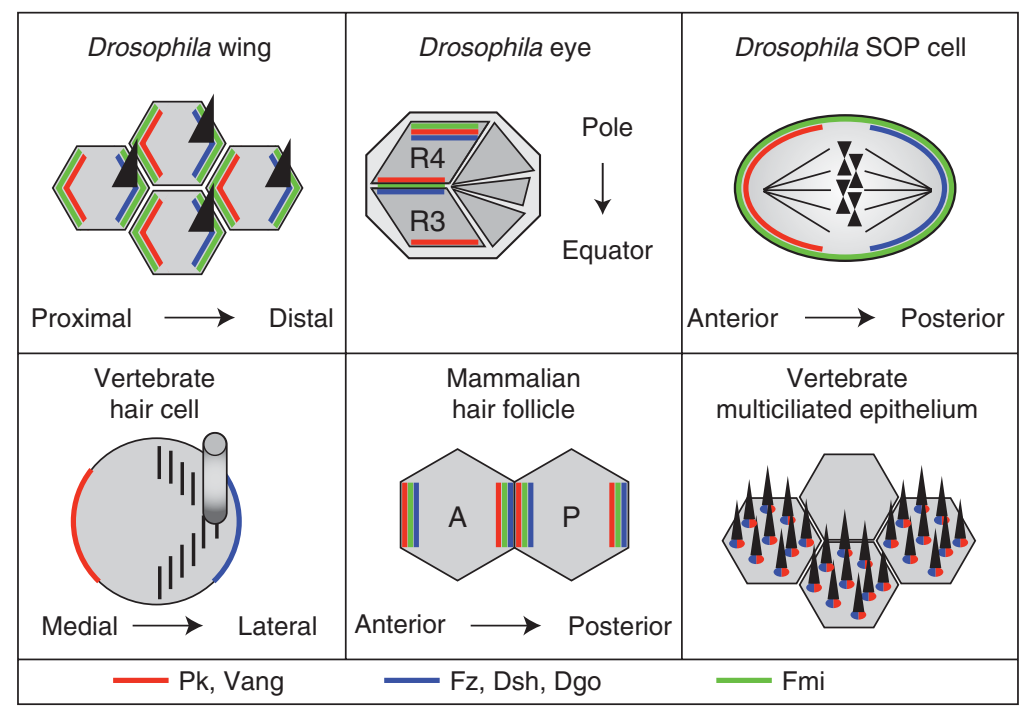

Figure 2. Core PCP protein distribution in planar polarized tissues in Drosophila and vertebrates. Asymmetric cortical distribution of core PCP components is a highly conserved feature of the PCP pathway. Pk/Vang and Fz/ Dsh/Dgo complexes segregate to opposite cortical domains in the fly wing, eye, SOP cell, and vertebrate sensory hair cell. The relative cortical distribution of PCP complexes remains untested in individual mammalian hair follicle precursor cells. Asymmetric cortical PCP complexes have not been reported in vertebrate multiciliated epithelial cells; instead, Dsh and Vang localize to the basal bodies.

(Cooper and Bray 1999; Fanto and Mlodzik 1999). Following R3/R4 determination, each ommatidium rotates in a direction determined by its newly acquired chirality. PCP components genetically interact with E-cadherin during ommatidial rotation, suggesting that the PCP pathway may also influence eye polarity through the remodeling of adherens junctions (Mirkovic and Mlodzik 2006).

Symmetry Breaking in PCP SignalingModels and Questions

The previously described PCP mechanism accounts for the polarization of individual cells and the alignment of neighbors, and may be thought of as an asymmetry amplifying and coordinating system that is then interpreted in cell-specific ways. However, an additional mechanism is needed to assure that the initial break in symmetry is biased in the correct direction with respect to a defined tissue axis. Several models have been proposed for this global directional cue, yet the mechanism remains controversial. The PCP protein $\mathrm{Fz}$ is also a receptor for Wingless (Wg, a Drosophila Wnt), mediating activation of the Wnt/ $\beta$-catenin pathway. Thus, the requirement for $\mathrm{Fz}$ in PCP initially suggested that $\mathrm{Wg}$ protein gradients might function upstream of the core PCP components to provide directional information. However, in flies, evidence argues against a direct function for any Drosophila Wnt in PCP establishment (Lawrence et al. 2002; Chen et al. 2008).

Initial confusion about the role of $\mathrm{Wg}$ in producing a global directional cue arose because, in the eye, graded $\mathrm{Wg} / \beta$-catenin pathway activity is responsible for graded activity of another set of PCP factors, including the Golgi protein Four-jointed $(\mathrm{Fj})$ and the large protocadherins, Fat (Ft) and Dachsous (Ds) (Wehrli and Tomlinson 1998; Yang et al. 2002). Studies of fly eye and wing polarity have led to a model in which Ft and Ds interact heterotypically to form asymmetric heterodimers that 
bridge cell boundaries, and through an unknown mechanism, provide directional bias to the core PCP mechanism (Yang et al. 2002; $\mathrm{Ma}$ et al. 2003; Matakatsu and Blair 2004; Simon 2004; Matakatsu and Blair 2006) (Fig. 1C). Fj acts to make Ft a better ligand for $\mathrm{Ds}$, and Ds a worse ligand for Ft. Because Fj is expressed in gradients, differences in Fj activity between neighboring cells leads to differences in production of Ft-Ds and Ds-Ft heterodimers at cell-cell interfaces (Yang et al. 2002; Ma et al. 2003). Furthermore, in all polarized Drosophila tissues examined, Ds and Fj are expressed in reciprocal gradients, thus potentially providing redundant and reinforcing information (Zeidler et al. 1999; Zeidler et al. 2000; Casal et al. 2002; Yang et al. 2002; Ma et al. 2003; Simon 2004). A recent study suggests that $\mathrm{Fj}$ is a Golgi-resident kinase that may regulate $\mathrm{Ft}$ and Ds activity through phosphorylation, although more convincing functional evidence is still needed (Ishikawa et al. 2008). Although in the eye, $\mathrm{Fj}$ and $\mathrm{Ds}$ expression gradients are controlled, at least in part, by $\mathrm{Wg}$, regulators of graded expression in other tissues are unknown.

Loss of Ft activity in the wing and eye uncouples the core PCP components from the global directional cue, but leaves their activity intact, so that polarity is no longer coordinated with the tissue axes (Yang et al. 2002; Ma et al. 2003; Simon 2004). Yet, wing cells still polarize and locally align their polarity, and ommatidia still polarize their R3/R4 fate choices, but in near random orientations. These results are consistent with the interpretation that the $\mathrm{Ft}$ system biases the direction of the core PCP feedback mechanism. Although most investigators now favor the model that $\mathrm{Ds} / \mathrm{Fj}$ expression gradients provide directional PCP information, several puzzles remain. First, studies in the abdomen suggest that, at least in that system, the $\mathrm{Ft} / \mathrm{Ds} / \mathrm{Fj}$ cassette might provide input to PCP establishment that bypasses the core PCP proteins, and thus the two systems might also have parallel function (Casal et al. 2006). Second, whereas $\mathrm{Fj}$ and Ds gradients exist in the wing and eye, their direction with respect to the direction of $\mathrm{Fz}$ accumulation is opposite, and in the abdomen, both relationships exist in different compartments (Casal et al. 2002; Yang et al. 2002; Ma et al. 2003). Third, unlike in the eye, replacing graded expression of $\mathrm{Fj}$ and $\mathrm{Ds}$ with uniform expression does not strongly affect PCP in the wing (Simon 2004), suggesting possible additional directional inputs to Ft. Thus, despite considerable progress, much about the global polarity cue and its linkage to the core PCP components remains unclear.

\section{PCP in Vertebrate Epithelia}

Planar polarized epithelia were observed in vertebrate tissues long before any understanding of the PCP pathway in Drosophila emerged. Vertebrate PCP homologs are now known to regulate the orientation of inner ear sensory hair cells, hair follicles of the skin, epithelial cells bearing multiple motile cilia, and others (reviewed in Zallen 2007; Simons and Mlodzik 2008). Mutant phenotypes first suggested that a conserved PCP pathway polarizes these epithelia, and more recently, evidence of conserved patterns of asymmetric subcellular localization of PCP proteins has reinforced this idea (Fig. 2). Our understanding of mechanism in these tissues derives largely from analogy to the fly system. However, additional observations have suggested novel aspects of PCP signaling in vertebrates. Understanding these systems is complicated by the existence of multi-gene families of PCP proteins, whereas flies have only one member of each gene family. Although the relative ease of genetic manipulation makes the fly an ideal model for studying PCP, the importance of PCP for human health and disease, for example, in polycystic kidney disease and metastatic cancers (reviewed in Simons and Walz 2006; Wallingford 2006; Simons and Mlodzik 2008; Jessen 2009), will continue to generate great interest in this pathway among those studying vertebrates.

The auditory and vestibular epithelia of the inner ear are now the best studied examples of vertebrate epithelial PCP, and existing evidence points to mechanistic conservation of the asymmetric cortical domain system first characterized in flies. Both types of inner ear epithelia 
contain hair cells that project an asymmetrically positioned kinocilium and an adjacent, asymmetrically distributed bundle of actin-based stereocilia. Hair cell PCP is essential for hearing and balance, and mutants in the mouse homologs of the core PCP components $\mathrm{Fz}$, Dsh (Dvl in vertebrates), Vang, Pk, and Fmi (Celsr in vertebrates) all have misoriented hair cells (reviewed in Kelly and Chen 2007). At least some core PCP homologs function redundantly, as only the disruption of multiple Fz and Dvl genes produces a substantial phenotype (Wang et al. 2006a; Wang et al. 2006b; Etheridge et al. 2008). Asymmetric membrane localization has been observed for Vangl2 (a Vang homolog), Pk2, Dvl2, Fz3, and Fz6 in both hair cells and the neighboring supporting cells that lack stereociliary bundles (Montcouquiol et al. 2006; Wang et al. 2006a; Wang et al. 2006b; Deans et al. 2007; Qian et al. 2007; Etheridge et al. 2008) (Fig. 2). At least in vestibular epithelia, Fz6 and Pk2 are on opposite sides of the cell, as are their fly homologs, and Vangl2 can tentatively be assigned to colocalize with $\mathrm{Pk} 2$, as in flies, though stronger evidence is still needed (Wang et al. 2006a; Wang et al. 2006b; Deans et al. 2007; Qian et al. 2007). Assignment of the relative orientation of Dvl proteins in vestibular epithelia and all of the proteins in the organ of Corti await further experiments.

In contrast to the fly, Wnt proteins appear to have $\beta$-catenin-independent PCP functions in inner ear sensory epithelia, based both on loss- and gain-of-function experiments for Wnt7a and Wnt5a, as well as the Wnt antagonist Frzb (Dabdoub et al. 2003; Qian et al. 2007). Furthermore, graded expression patterns of these proteins suggest the possibility that they could provide directional information to the PCP system, but functional evidence for this is lacking. Although most attention has been paid to the possibility of a direct role for Wnts, the recent finding that disruption of Fat4 in mice produces inner ear PCP defects (Saburi et al. 2008) is also consistent with the possibility that Wnts shape the activity of a $\mathrm{Ft} / \mathrm{Ds} / \mathrm{Fj}$ cassette, as is observed in the fly eye. On the other hand, because Wnt gradients were recently proposed to have a more direct instructive function in other tissues (Gros et al. 2008; He et al. 2008) (see below), it is possible that additional experiments will uncover such a role for Wnts in the ear. The possible presence and requirement of nonWnt activators of Fz and, conversely, of alternative Wnt receptors should also be considered in both fly and vertebrate systems.

The orientation of hair follicles in mammalian skin is also under PCP control. Fz6 single mutant mice are viable with misoriented hair follicles (Guo et al. 2004), and Vangl2 and Celsr1 (Fmi) mutant embryos also have misaligned hair follicles (Devenport and Fuchs 2008). Similar to flies, asymmetric recruitment of Vangl2 and Fz6 to cortical domains occurs in hair follicle precursor cells, apparently through homotypic Celsr1 interactions between neighboring cell surfaces (Fig. 2) (Devenport and Fuchs 2008). Intriguingly, the finding that these PCP proteins are required for early anterior-posterior compartmentalization of the hair germ, which grows to hundreds of cells in size, suggests the possibility that the first two hair germ cells might adopt positionspecific anterior or posterior cell fates by a mechanism similar to that which distinguishes the R3 and R4 photoreceptors in the fly eye. Primary cilia may also be involved in hair follicle PCP, as follicles are also misoriented in a mutant for the ciliary component Inversin (Simons et al. 2005) (see below).

The PCP pathway is implicated in the polarized alignment of motile cilia in multiciliated epithelia (Park et al. 2008). Multiciliated epithelial cells each contain hundreds of motile cilia that are physically aligned according to the direction of the ciliary beat both within each cell and among neighboring cells (BoisvieuxUlrich et al. 1985). Multiciliated epithelia are present in vertebrate airways, oviduct, ependyma, and in the frog embryonic skin where a role for Dvl and the PCP effectors Fy and In was identified (Park et al. 2006; Park et al. 2008). Morpholino depletion of all three proteins blocked ciliogenesis, although a specific mutant allele of Dvl permitted ciliogenesis, but disrupted the planar polarized alignment 
and beat pattern of the cilia. These PCP proteins localized only to basal bodies, and Vangl2 has also been observed in respiratory epithelial basal bodies and axonemes (Ross et al. 2005). Thus, no evidence has yet been reported to suggest that the PCP mechanism functions through the establishment of asymmetric cortical domains in ciliated epithelial cells, and the observed requirements could in principle be independent of the conserved PCP mechanism.

\section{DIRECTED CELL MOTILITY}

\section{Convergent Extension}

The finding that multiple PCP genes in several organisms are required for proper embryonic convergent extension (CE), a process of mediolateral narrowing (convergence) and rostrocaudal extension of vertebrate embryos during gastrulation (Keller 2002; Keys et al. 2002; Wallingford et al. 2002; Solnica-Krezel 2006), strongly suggests a PCP-like mechanism. During CE, cells of the axial and paraxial mesoderm and neuroectoderm become morphologically polarized, elongating and aligning along the medio-lateral axis. They develop mediolateral lamellipodia, and actively and directionally crawl between neighboring cells towards the dorsal midline, in a process that entails considerable exchanging of cell neighbors. Impairment of cell polarization results in embryos with short and wide body axes and with severe open neural tube defects (Wallingford and Harland 2002; Wang and Nathans 2007; YbotGonzalez et al. 2007).

In addition to $\mathrm{CE}$ driving embryonic axis elongation, disruption of PCP proteins is associated with $\mathrm{CE}$ defects in the mouse cochlea, kidney, and the heart outflow tract primordium (Henderson et al. 2001; Wang et al. 2005; Fischer et al. 2006). CE driving embryonic axis elongation in Xenopus and zebrafish is by far the most studied of these.

Mutation of core PCP molecules disrupts embryonic axis CE without affecting cell fate. Xenopus and zebrafish Dsh (Dvl) (Tada and Smith 2000; Wallingford et al. 2000; Wallingford and Harland 2001), Fz7 (Djiane et al. 2000), Vangl2 (Strabismus [Stbm]/ Trilobite[Tri]) (Sepich et al. 2000; Darken et al. 2002; Jessen et al. 2002; Vervenne et al. 2008), Pk (Carreira-Barbosa et al. 2003; Takeuchi et al. 2003; Veeman et al. 2003), and Fmi (Celsr) (Formstone and Mason 2005; Carreira-Barbosa et al. 2009) are needed for $\mathrm{CE}$, and when lost, failure of cells to correctly elongate and align in the medio-lateral axis is observed. Although considerable genetic evidence indicates an important role for PCP components in $\mathrm{CE}$, it is not clear that they function as in epithelial PCP.

In zebrafish and Xenopus, identifying asymmetric cortical distributions of PCP proteins similar to those seen in typical epithelial PCP examples described above has proven difficult. In the zebrafish neural keel and notochord, $\mathrm{Pk}$ protein has been observed in a punctate distribution along the anterior of migrating cells (Ciruna et al. 2006). In dorsal mesoderm, proximal Pk and distal Dsh are observed in punctae, but the punctae are sparse, and required quantification to convincingly show asymmetric distribution (Yin et al. 2008). Perhaps the punctae represent transient accumulations of typical core PCP complexes that are established as cells make and break contacts with neighbors. Consistent with this idea, Pk and Dsh punctae lose their asymmetric distribution in a trilobite (zebrafish Vang) mutant (Ciruna et al. 2006; Yin et al. 2008). However, demonstrating a conserved mechanism will require showing functional interactions between asymmetrically localized PCP proteins in neighboring cells. A somewhat different arrangement is seen in the Ciona notochord, which undergoes a simple CE movement that depends on the Pk homolog, Aimless, and on Dsh (Keys et al. 2002; Jiang et al. 2005; Ciruna et al. 2006). Aimless and Vang are seen at the anterior of converging and extending notochord cells, but Dsh is seen at the lateral edges (Jiang et al. 2005; Ciruna et al. 2006). Although these domains are not a simple recapitulation of the opposite proximal and distal domains seen in epithelial tissues, one can imagine a common mechanism.

Similar to vertebrate epithelial PCP, cell migration during Xenopus CE involves 
$\beta$-catenin independent Wnt5a and Wnt11 signaling, as shown using morpholino knockdown and overexpression (Heisenberg et al. 2000; Wallingford et al. 2001; Kilian et al. 2003; Ulrich et al. 2003). Interestingly, these two signals do not regulate $\mathrm{CE}$ in the same manner, producing different effects at the morphological level (Schambony and Wedlich 2007). Similarly, different effects of these two Wnts are observed on cellular behaviors. Depletion of Wnt11 causes a complete loss of lamellipodia formation and strong inhibition of motility. In contrast, Wnt5a-depleted cells form disorganized lamellipodia. These cells fail to align mediolaterally, they do not display coordinated polarity, and they move in random directions. Morphologically, Wnt11 knockdown more closely resembles knockdown of the core PCP proteins, and Wnt11 injection could not rescue the Wnt5a knockdown phenotype.

The distinct effects of Wnt5a and Wnt11 on cellular behavior and convergent extension are reflected in differences in the signaling pathways activated by these two Wnts. In Xenopus and in zebrafish, Wnt11 physically interacts with Fz7 and induces Dvl (Dsh) accumulation at the plasma membrane (Djiane et al. 2000; Winklbauer et al. 2001; Witzel et al. 2006), activating a pathway involving a formin homology protein Daam-1 (Habas et al. 2001), WGEF (weak-similarity guanine nucleotide-exchange factor), RhoA and Rok, leading to formation of focal adhesion complexes, and stress fibers (Habas et al. 2001; Tahinci and Symes 2003; Wallar and Alberts 2003; Kovar 2006a; Kovar 2006b; Vavylonis et al. 2006; Zhu et al. 2006; Tanegashima et al. 2008). Additional GEFs may operate to activate Rac1 and Cdc42, which induce formation of lamellipodia and filopodia, respectively. Wnt11 has also been shown to affect cell adhesion through control of E-cadherin subcellular localization (Ulrich et al. 2005; Witzel et al. 2006; Palamidessi et al. 2008; Zech and Machesky 2008). In contrast, Wnt5a signaling in Xenopus is mediated by the Ror2/JNK signaling cascade involving PI3K, Cdc42, JNK, MKK7, and transcription factors c-jun and ATF2 (Schambony and Wedlich 2007). One result is direct transcriptional up-regulation of the paraxial protocadherin (XPAPC). Cells that are depleted of XPAPC fail to align mediolaterally and they move randomly, fully phenocopying the knockdown of Wnt5a.

These findings suggest that two Wnt molecules, Wnt5a and Wnt11, operate by engaging two different downstream signaling cascades. However, they do not reveal the mechanisms that produce asymmetry during $\mathrm{CE}$, nor do they indicate how their functions relate to those of the core PCP regulators, such as Prickle or Vang. Although it has been widely assumed that Wnts somehow activate core PCP components, there is no evidence that Wnts provide directional information in any of these systems. Indeed, Wnt11 zebrafish mutants can be rescued by early injection of Wnt11 mRNA, which produces presumably uniform expression of Wnt11. This suggests the absence of a requirement for localized expression (Heisenberg et al. 2000). It is instead possible that Wnts activate effectors with activities oriented by the core PCP proteins, and thus act permissively rather than instructively.

\section{Cell Migration}

Cell migration is crucial for countless developmental, homeostatic and, regenerative processes. Compared to the characteristic movements that define convergent extension, other cell migration processes often involve directed motility over significantly larger distances. The PCP pathway has been firmly implicated in the directional migration of some neurons (Bingham et al. 2002; Carreira-Barbosa et al. 2003; Wada et al. 2006) and of neural crest cells (De Calisto et al. 2005; Shnitsar and Borchers 2008). In each case, the migrating cells follow a stereotyped trajectory. Similar to convergent extension, PCP components appear to regulate cytoskeletal changes, protrusive membrane activity, cell-cell adhesion, and the trajectory of migration.

One interesting example is the control of zebrafish facial motor neuron migration by the PCP pathway. In Vangl2, Pk1, Fz3, and $\mathrm{Fmi} / \mathrm{Celsr} 2$ mutants, migration is abolished or 
E.K. Vladar, D. Antic, and J.D. Axelrod

its normal directionality lost (Bingham et al. 2002; Carreira-Barbosa et al. 2003; Wada et al. 2006). Mosaic analysis revealed that Fz3 and Celsr2 act nonautonomously, as wild-type neurons failed to migrate along the mutant-derived neuroepithelium (Wada et al. 2006). This raises the possibility that cell-cell interactions, possibly mediated by homotypic interaction of Celsr, may shape the trajectory of migrating facial motor neurons. Despite Fz3 involvement, neither Wnt11 nor Wnt5a mutation affect migration in zebrafish (Bingham et al. 2002; Jessen et al. 2002).

Neural crest (ectomesenchymal) cells arise from the neural fold, then migrate away to give rise to multiple cell types. Wnt/ $\beta$-catenin and other signals are needed to induce neural crest cell fate, whereas the PCP pathway is required for their migration (De Calisto et al. 2005; Shnitsar and Borchers 2008). Wnt11 is expressed in the adjacent ectoderm and acts through Fz7 and the receptor Protein tyrosine kinase 7 (Ptk7) to stimulate migration. Grafting and ubiquitous expression experiments suggested that localization of the Wnt11 signal might provide a directional cue for migration, but other experiments are difficult to reconcile with this possibility (De Calisto et al. 2005; Shnitsar and Borchers 2008). A fascinating model for the role of core PCP signaling in neural crest migration comes from the observation that Wnt11, Dsh, Pk, and Vang are required for "contact inhibition of locomotion," a phenomenon in which a cell becomes polarized and initiates sustained directional migration away from contact with another neural crest cell (Fig. 3) (Carmona-Fontaine et al. 2008). Remarkably, Wnt11, Fz7, and Dsh accumulate at contacting cell surfaces, RhoA is activated, and lamellipodia are locally inhibited, producing a polarized cell. Thus, core PCP proteins might contribute to migratory behavior by indicating cell-cell contact and initiating crawling away from points of contact. It will be important to ascertain the arrangement of PCP proteins at the contact sites and to determine how signaling complexes compare to those involved in epithelial PCP. According to this model, Wnt11 is required for polarized migration without providing directional information.

Outside the developing nervous system, there is evidence that the PCP pathway regulates endothelial cell migration during angiogenesis (Cirone et al. 2008) and disease-induced vascular remodeling (Laumanns et al. 2009; de Jesus Perez et al. 2009). Much remains to be learned about how the PCP pathway contributes to the directional motility needed to transport and orient endothelial cells at sites of new blood vessel growth.

\section{ORIENTED OR ASYMMETRIC CELL DIVISION}

Oriented and asymmetric cell divisions occur frequently throughout development to
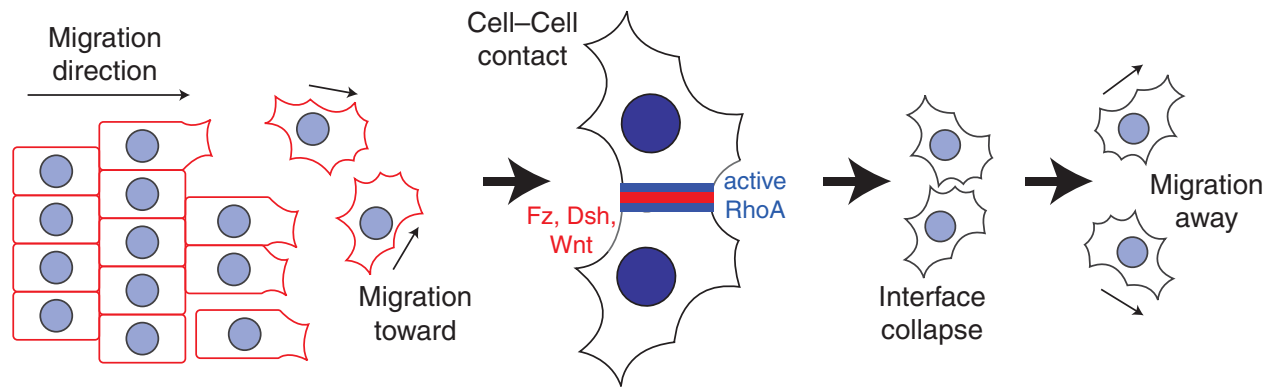

Figure 3. PCP components regulate contact inhibition of locomotion in migrating neural crest cells. Schematic of neural crest cell migration showing cells breaking away from the epithelial sheet leading edge, migrating toward each other, and forming an interface, which then collapses and prompts cells to migrate in opposite directions. Initially, PCP components have uniform distributions, but then relocalize to the site of cell-cell contact. PCP components are required to arrest and then alter the migration path, possibly through activation of RhoA. 
determine cellular position, morphology, and cell fate, and PCP involvement in these processes is not surprising. Both oriented and asymmetric cell divisions depend on positioning of the cleavage plane, producing daughter cells in a specific orientation or with asymmetric cell size and protein content (reviewed in Gonczy 2008). Such PCP-controlled divisions have been observed in flies, worms, and vertebrates; however, the mechanism in many cases remains unknown (Zallen 2007; Simons and Mlodzik 2008). Cytoskeletal dynamics are central to mitotic spindle orientation and cleavage plane generation during cell division (McCarthy and Goldstein 2006). Because the PCP pathway is a known modulator of cytoskeletal elements in other polarized systems, it is likely that it also functions in that context in dividing cells. In at least one example, the mechanism by which PCP regulates an oriented and asymmetric cell division is reasonably well understood, but in most instances the mechanisms are poorly characterized.

The proper generation of sensory bristles that cover the adult Drosophila epidermis requires the oriented and asymmetric division of sensory organ precursor (SOP) cells along the anterior-posterior (A-P) axis. In core PCP mutants, SOP cell mitotic spindle orientation is randomized, and the divisions sometimes become symmetric (Betschinger and Knoblich 2004; Roegiers and Jan 2004). Similar to wing epithelial and ommatidial photoreceptor cells, Fmi is uniformly distributed at the cortex ( $\mathrm{Lu}$ et al. 1999), and the Vang/Pk and Fz/Dsh PCP complexes localize to opposite asymmetric membrane domains along the A-P axis (Bellaiche et al. 2001a; Bellaiche et al. 2004) (Fig. 2). On entry into mitosis, these domains mediate the recruitment of the Dlg-Pins-G $\alpha \mathrm{i}$ and Par3/Par6/aPKC complexes to the anterior and posterior sides, respectively (Bellaiche et al. 2001b; Roegiers et al. 2001), where they regulate spindle morphology and orientation by modulating interactions between microtubules and the cortex (Roegiers and Jan 2004).

In Caenorhabditis elegans, numerous asymmetric cell divisions are regulated by Wnt signaling. Localized Wnt expression differentially activates Fz-dependent pathways that control levels of $\beta$-catenin activity in the two daughter nuclei, thus leading to differential cell fates (Betschinger and Knoblich 2004; Mizumoto and Sawa 2007). In at least one wellcharacterized case, the position of the Wnt signal determines orientation of the mitotic spindle (Goldstein et al. 2006). Interestingly, in other divisions, worm $\beta$-catenin and APC have been observed at cell cortices, but it is thought that this reflects differential regulation of $\beta$-catenin nuclear entry in the daughter cells (Betschinger and Knoblich 2004; Mizumoto and Sawa 2007). In Wnt-dependent asymmetric division of the C. elegans B cell, Fz and Dsh localize asymmetrically, and $\mathrm{Fz}$ asymmetric localization depends on Wnt and Dsh (Wu and Herman 2006). Selective requirement for Dsh domains, and requirements for the downstream PCP effectors RhoA and ROCK, also suggest a more PCP-like mechanism (Wu and Herman 2006). Recently, two oriented cell divisions, of the P5.p and P7.p cells that contribute to vulval development, have been shown to be under control of both a $\beta$-catenin dependent Wnt pathway, and a newly identified pathway that requires a different Wnt, the worm Ror receptor tyrosine kinase and worm Vang (Green et al. 2008). Although not well understood, this Vang-dependent pathway does not require JNK signaling and does not depend on $\beta$-catenin-regulated transcription, suggesting that the primary target may be orientation of the mitotic spindle. Vang subcellular localization was not determined in P5.p and P7.p cells, and it is unknown how Vang functions in this context. These examples notwithstanding, it is remarkable that despite extensive study of asymmetric cell divisions in worms, most have produced no evidence of a role for PCP proteins.

In several other instances, PCP proteins have been shown to orient cell divisions, but the mechanism is not known. Preceding CE, zebrafish dorsal epiblast cells divide along the animal-vegetal $(\mathrm{A}-\mathrm{V})$ axis of the embryo in a PCP-dependent manner, and this is important for CE (Gong et al. 2004). Another such example is the developing mammalian kidney, where 
oriented cell division followed by CE movements is required for kidney tubule elongation, and disruption of this process leads to polycystic kidney formation (Fischer et al. 2006). Recent work implicated Fat4, the closest mammalian homolog of the Drosophila PCP protein $\mathrm{Ft}$, in the alignment of dividing cells and kidney tubule elongation (Saburi et al. 2008). In the fly, Ft and Ds are thought to influence the core PCP proteins to provide directional information (see above). However, independent of the core PCP machinery, they are also involved in oriented cell divisions that contribute to wing axis elongation (BaenaLopez et al. 2005). Genetic interaction between Fat 4 and both Fjx1, the mouse Fj homolog, and Vangl2 in the kidney are suggestive of a conserved PCP mechanism. Similar to Vangl2 (Ross et al. 2005), Fat4 is present in primary cilia in cultured kidney cells (Saburi et al. 2008), in contrast to the apicolateral membrane localization observed in flies (Ma et al. 2003). The association of primary cilia with $\mathrm{PCP}$ signaling is discussed later.

\section{ASYMMETRIC CELLULAR MORPHOLOGY IN NEURONS AND OTHER CELLS}

PCP components have been implicated in regulation of neuronal and nonneuronal cellular morphology and shape changes, and in axon guidance (reviewed in Wang and Nathans 2007; Goodrich 2008). Although mostly not well characterized, the mechanism is likely distinct in each case, even though the common involvement of at least some PCP genes suggests an underlying molecular relationship.

Several mouse PCP mutants were found to have forebrain axon growth defects. Axon tracts that connect the cortex and the thalamus are absent in $\mathrm{Fz} 3$ and Celsr3 (Fmi) mutants, although neuronal proliferation, migration, and gross forebrain morphology are unaffected (Wang et al. 2002; Tissir et al. 2005; Wang et al. 2006c). Spinal cord axon guidance defects are also seen in both mutant mice (Wang et al. 2002; Lyuksyutova et al. 2003), and rostral turning of the affected spinal neurons was stimulated by the addition of several Wnt proteins. This included Wnt4, which is distributed in a rostral-caudal gradient along the spinal cord (Lyuksyutova et al. 2003), suggesting that it may function as a longitudinally diffusible polarity cue in axon guidance. Further work is needed to test whether Wnt4 or other Wnts activate Fz3 in this process. Determining whether asymmetric membrane recruitment or regulation of cytoskeletal elements occur will be important for understanding the mechanism through which PCP components control axon guidance.

The PCP pathway and the Par3/Par6/aPKC complex together regulate several PCP processes (Bellaiche et al. 2004; Hyodo-Miura et al. 2006) and may similarly cooperate in the CNS in axonal growth and guidance. In vitro evidence suggests that Wnt-PCP signaling acts through the Par complex via Dvl-mediated aPKC activation in neuronal polarization, axon growth, and guidance (Zhang et al. 2007; Wolf et al. 2008; see Tahirovic and Bradke 2009). Whether and how this mechanism might provide directional information remains to be determined.

Some PCP proteins are involved in polarization of other neurons, but possibly independently of the PCP pathway. Both Drosophila and mammalian Fmi/Celsr proteins affect the outgrowth and morphology of dendrites (Gao et al. 2000; Shima et al. 2004; Kimura et al. 2006), and mouse Dvll has a similar affect on hippocampal neurons (Rosso et al. 2005). However, $f z$ mutant flies have normal dendritic morphology (Gao et al. 2000), and other fly PCP mutants have not been reported to show related neuronal phenotypes. Thus, this function may not involve the PCP pathway per se.

PCP signaling was also recently implicated in the organization and elongation of chick early skeletal muscle fibers in developing somites (Gros et al. 2008). Prospective myocytes along the neural tube transform from their initial epithelial morphology into elongated, parallel stacks aligned with the A-P axis of the embryo. This process entails the formation of lamellipodia at their anterior and posterior ends, reminiscent of the oriented elaboration of cellular processes during CE movements. 
Similar to some cases of CE (Heisenberg et al. 2000), Wnt11 was shown be essential both for the elongation and alignment of the myocytes (Gros et al. 2008). Disruption of multiple other core PCP homologs also led to loss of myocyte alignment, confirming that Wnt11 signals through the PCP pathway, and ROCK and JNK signaling are also required. Compelling evidence was presented that a localized source of Wnt11 is an instructive directional signal upstream of the PCP pathway for myocytes undergoing elongation and alignment. On what receptor the Wnt acts was not determined.

During mouse palate development, mesenchymal cells have been shown to undergo a Wnt5a/Ror2-dependent migration, and bead implant studies suggest a chemoattractant role for Wnt5a (He et al. 2008). These two examples run counter to the more common interpretation that Wnts provide a permissive signal rather than directional information. It will be important to identify the direct targets of Wnts in these systems.

\section{CILIA: ANTENNAE FOR PCP SIGNALING?}

Primary cilia are evolutionarily conserved structures that consist of a microtubule-based axoneme anchored to the apical cell surface via the basal body and enclosed by a specialized membrane. Most primary cilia are immotile and function to sense the extracellular environment. Primary cilia have been linked to PCP, both as structures responsive to PCP information, and also as structures potentially involved in transducing PCP information (Singla and Reiter 2006).

Both primary cilia and motile cilia often require asymmetric placement or orientation for normal function (Boisvieux-Ulrich et al. 1985; Mitchell et al. 2007; Park et al. 2008; see Hirokawa et al. 2009), and in several cases the PCP signaling pathway has been shown to provide this information. Recent studies of multiciliated epithelial cells of the Xenopus epidermis revealed that Dvl and the PCP effector proteins Inturned, Fuzzy and Rho work together to regulate exocyst-mediated vesicle-based docking, as well as subsequent polarization of basal bodies necessary for coordinated orientation and functional beating of multicilia (Park et al. 2006; Park et al. 2008).

In sensory epithelia of the inner ear, the kinocilium, a specialized primary cilium on sensory hair cells, emerges in the cell center and then migrates directionally. An array of stereocilia organizes around the kinocilium in an asymmetric pattern necessary for function (Denman-Johnson and Forge 1999). Conditional knockout mutagenesis of either of two ciliary proteins, IFT88 (Polaris) or KIF3A, blocked kinocilium formation, and revealed that kinocilia are required for proper positioning of basal bodies, morphological polarization of individual stereociliary bundles, and their coordinated alignment within the organ of Corti (Jones et al. 2008). Ift88 was found to genetically interact with Vangl2 in this process. Interestingly, the asymmetric cortical distribution of the two core PCP proteins, Vangl2 and Fz3, was normal in cochleas of Ift 88 conditional mutants. Because asymmetric distribution of at least these two PCP proteins is normal, it seems reasonable to conclude that kinocilia are required for basal bodies to interpret or execute polarization signals from PCP proteins in asymmetric cortical domains.

Additional data, however, suggest that primary cilia might serve also as signaling centers important for regulating PCP. Some phenotypes associated with human diseases that affect primary cilia, such as polycystic kidney disease, nephronophthisis, and Bardet-Biedl Syndrome (BBS), as well as some phenotypes associated with mouse ciliary mutants, are attributable to PCP defects (Morgan et al. 1998; Marszalek et al. 1999; Lin et al. 2003; Otto et al. 2003; Ross et al. 2005; Park et al. 2006; Patel et al. 2008; Ferrante et al. 2009). The majority of the phenotypes associated with these mutations are not obviously attributable to asymmetric localization or orientation of primary cilia, suggesting a function for primary cilia other than as a target of the PCP system. BBS proteins localize to basal bodies and regulate ciliary membrane biogenesis and vesicular transport through the cilium (Nachury et al. 2007), indicating that protein and/or membrane 
trafficking at basal bodies and/or kinocilia are important for planar polarity. Recently, cilia have been identified as organelles involved in intercellular signal transduction. Receptors, ion channels, effector proteins, and even transcription factors move in and out of cilia on exposure of cells to morphogenetic signals such as Shh (Rohatgi et al. 2007) or PDGF (Schneider et al. 2005). Although receptors for Wnts have not been identified in primary cilia, other evidence implies a function for primary cilia in regulating both canonical and PCP signaling (Simons et al. 2005; Singla and Reiter 2006; Gerdes et al. 2007; Corbit et al. 2008). It may therefore be significant that Vangl2 (Ross et al. 2005) and Fat 4 (Saburi et al. 2008) localize to primary cilia in a kidney cell line, though Vangl2 was not similarly detected at the kinocilia of mouse cochlea (Montcouquiol et al. 2006). Hence, it is tempting to speculate that primary cilia serve as antennae for transduction of PCP signals. Wnts are obvious candidates for this signal, though other signals should also be considered. The transducers of this signal, and how it interacts with the asymmetric cortical domains of PCP proteins, are unknown.

\section{CONCLUDING REMARKS}

Genetic analyses have identified functions for core PCP proteins in a variety of processes involving cellular asymmetry in organisms ranging from worms to flies to vertebrates. In epithelia, the core PCP proteins function to amplify and reinforce asymmetry within cells by a mechanism that entails contact and cooperation with neighboring cells, and results in the redistribution of the core PCP proteins into asymmetric cortical domains. These proteins respond to directional information related to the tissue axes, and in most cases function to orient cytoskeletal reorganization to execute morphogenetic responses. However, the same proteins also participate in generating cellular asymmetry in other, nonepithelial systems, in which mechanistic similarities are less evident. Because cells in many of these systems are changing neighbors more rapidly than in epithelia, adaptations of the basic mechanism are likely required, perhaps retaining their ability to orient cytoskeletal changes while responding to asymmetry cues in differing ways. One dramatic difference between PCP in vertebrates and lower organisms is the possible requirement for primary cilia in transducing some PCP signals. We expect that the resurgent interest in primary cilia will drive rapid advances in determining their role in PCP. As our knowledge of these various systems increases, it will be interesting to learn whether they are in fact more or less similar to each other than they now appear to be.

\section{ACKNOWLEDGMENTS}

Work in the Axelrod lab is supported by grants from the National Institutes of Health.

\section{REFERENCES}

Adler PN. 1992. The genetic control of tissue polarity in Drosophila. BioEssays 14: 735-741.

Adler PN, Taylor J, Charlton J. 2000. The domineering nonautonomy of frizzled and van Gogh clones in the Drosophila wing is a consequence of a disruption in local signaling. Mech Dev 96: 197-207.

Amonlirdviman K, Khare NA, Tree DR, Chen WS, Axelrod JD, Tomlin CJ. 2005. Mathematical modeling of planar cell polarity to understand domineering nonautonomy. Science 307: 423-426.

Axelrod JD, McNeill H. 2002. Coupling planar cell polarity signaling to morphogenesis. ScientificWorldJournal 2: 434-454.

Baena-Lopez LA, Baonza A, Garcia-Bellido A. 2005. The orientation of cell divisions determines the shape of Drosophila organs. Curr Biol 15: 1640-1644.

Bastock R, Strutt H, Strutt D. 2003. Strabismus is asymmetrically localised and binds to Prickle and Dishevelled during Drosophila planar polarity patterning. Development 130: 3007-3014.

Bellaiche Y, Beaudoin-Massiani O, Stuttem I, Schweisguth F. 2004. The planar cell polarity protein Strabismus promotes Pins anterior localization during asymmetric division of sensory organ precursor cells in Drosophila. Development 131: 469-478.

Bellaiche Y, Gho M, Kaltschmidt JA, Brand AH, Schweisguth F. 2001a. Frizzled regulates localization of cell-fate determinants and mitotic spindle rotation during asymmetric cell division. Nat Cell Biol 3: 50-57.

Bellaiche Y, Radovic A, Woods DF, Hough CD, Parmentier ML, O’Kane CJ, Bryant PJ, Schweisguth F. 2001b. The Partner of Inscuteable/Discs-large complex is required 
to establish planar polarity during asymmetric cell division in Drosophila. Cell 106: 355-366.

Betschinger J, Knoblich JA. 2004. Dare to be different: Asymmetric cell division in Drosophila, C. elegans and vertebrates. Curr Biol 14: R674-685.

Bingham S, Higashijima S, Okamoto H, Chandrasekhar A. 2002. The Zebrafish trilobite gene is essential for tangential migration of branchiomotor neurons. Dev Biol 242: 149-160.

Boisvieux-Ulrich E, Laine MC, Sandoz D. 1985. The orientation of ciliary basal bodies in quail oviduct is related to the ciliary beating cycle commencement. Biol Cell 55: $147-150$.

Carmona-Fontaine C, Matthews HK, Kuriyama S, Moreno M, Dunn GA, Parsons M, Stern CD, Mayor R. 2008 Contact inhibition of locomotion in vivo controls neural crest directional migration. Nature 456: 957-961.

Carreira-Barbosa F, Concha ML, Takeuchi M, Ueno N, Wilson SW, Tada M. 2003. Prickle 1 regulates cell movements during gastrulation and neuronal migration in zebrafish. Development 130: 4037-4046.

Carreira-Barbosa F, Kajita M, Morel V, Wada H, Okamoto H, Martinez Arias A, Fujita Y, Wilson SW, Tada M. 2009. Flamingo regulates epiboly and convergence/ extension movements through cell cohesive and signalling functions during zebrafish gastrulation. Development 136: 383-392.

Casal J, Lawrence PA, Struhl G. 2006. Two separate molecular systems Dachsous/Fat and Starry night/Frizzled, act independently to confer planar cell polarity. Development 133: 4561-4572.

Casal J, Struhl G, Lawrence PA. 2002. Developmental compartments and planar polarity in Drosophila. Curr Biol 12: $1189-1198$.

Chae J, Kim MJ, Goo JH, Collier S, Gubb D, Charlton J, Adler PN, Park WJ. 1999. The Drosophila tissue polarity gene starry night encodes a member of the protocadherin family. Development 126: 5421-5429.

Chen WS, Antic D, Matis M, Logan CY, Povelones M, Anderson GA, Nusse R, Axelrod JD. 2008. Asymmetric homotypic interactions of the atypical cadherin flamingo mediate intercellular polarity signaling. Cell 133: 1093-1105.

Cirone P, Lin S, Griesbach HL, Zhang Y, Slusarski DC, Crews CM. 2008. A role for planar cell polarity signaling in angiogenesis. Angiogenesis 11: 347-360.

Ciruna B, Jenny A, Lee D, Mlodzik M, Schier AF. 2006. Planar cell polarity signalling couples cell division and morphogenesis during neurulation. Nature 439: $220-224$.

Collier S, Gubb D. 1997. Drosophila tissue polarity requires the cell-autonomous activity of the fuzzy gene which encodes a novel transmembrane protein. Development 124: 4029-4037.

Cooper MT, Bray SJ. 1999. Frizzled regulation of Notch signalling polarizes cell fate in the Drosophila eye. Nature 397: 526-530.

Corbit KC, Shyer AE, Dowdle WE, Gaulden J, Singla V, Chen MH, Chuang PT, Reiter JF. 2008. Kif3a constrains $\beta$-catenin-dependent Wnt signalling through dual ciliary and non-ciliary mechanisms. Nat Cell Biol 10: 70-76.

Dabdoub A, Donohue MJ, Brennan A, Wolf V, Montcouquiol M, Sassoon DA, Hseih JC, Rubin JS, Salinas PC, Kelley MW. 2003. Wnt signaling mediates reorientation of outer hair cell stereociliary bundles in the mammalian cochlea. Development 130: 2375-2384.

Darken RS, Scola AM, Rakeman AS, Das G, Mlodzik M, Wilson PA. 2002. The planar polarity gene strabismus regulates convergent extension movements in Xenopus. EMBO J 21: 976-985.

Das G, Jenny A, Klein TJ, Eaton S, Mlodzik M. 2004. Diego interacts with Prickle and Strabismus/Van Gogh to localize planar cell polarity complexes. Development 131: 4467-4476.

Das G, Reynolds-Kenneally J, Mlodzik M. 2002. The atypical cadherin Flamingo links Frizzled and Notch signaling in planar polarity establishment in the Drosophila eye. Dev Cell 2: 655-666.

De Calisto J, Araya C, Marchant L, Riaz CF, Mayor R. 2005. Essential role of non-canonical Wnt signalling in neural crest migration. Development 132: 2587-2597.

de Jesus Perez VA, Alastalo TP, Wu JC, Axelrod JD, Cooke JP, Amieva M, Rabinovitch M. 2009. Bone morphogenetic protein 2 induces pulmonary angiogenesis via Wnt$\beta$-catenin and Wnt-RhoA-Racl pathways. J Cell Biol 184: 83-99.

Deans MR, Antic D, Suyama K, Scott MP, Axelrod JD, Goodrich LV. 2007. Asymmetric distribution of pricklelike 2 reveals an early underlying polarization of vestibular sensory epithelia in the inner ear. J Neurosci 27: 3139-3147.

Denman-Johnson K, Forge A. 1999. Establishment of hair bundle polarity and orientation in the developing vestibular system of the mouse. J Neurocytol 28: 821-835.

Devenport D, Fuchs E. 2008. Planar polarization in embryonic epidermis orchestrates global asymmetric morphogenesis of hair follicles. Nat Cell Biol 10: 1257-1268.

Djiane A, Riou J, Umbhauer M, Boucaut J, Shi D. 2000. Role of frizzled 7 in the regulation of convergent extension movements during gastrulation in Xenopus laevis. Development 127: 3091-3100.

Etheridge SL, Ray S, Li S, Hamblet NS, Lijam N, Tsang M, Greer J, Kardos N, Wang J, Sussman DJ, et al. 2008. Murine dishevelled 3 functions in redundant pathways with dishevelled 1 and 2 in normal cardiac outflow tract cochlea and neural tube development. PLoS Genet 4: e1000259.

Fanto M, Mlodzik M. 1999. Asymmetric Notch activation specifies photoreceptors R3 and R4 and planar polarity in the Drosophila eye. Nature 397: 523-526.

Feiguin F, Hannus M, Mlodzik M, Eaton S. 2001. The ankyrin repeat protein Diego mediates Frizzleddependent planar polarization. Dev Cell 1: 93-101.

Ferrante MI, Romio L, Castro S, Collins JE, Goulding DA, Stemple DL, Woolf AS, Wilson SW. 2009. Convergent extension movements and ciliary function are mediated by ofd1, a zebrafish orthologue of the human oral-facialdigital type 1 syndrome gene. Hum Mol Genet 18: 289-303. 
E.K. Vladar, D. Antic, and J.D. Axelrod

Fischer E, Legue E, Doyen A, Nato F, Nicolas JF, Torres V, Yaniv M, Pontoglio M. 2006. Defective planar cell polarity in polycystic kidney disease. Nat Genet 38: $21-23$.

Formstone CJ, Mason I. 2005. Combinatorial activity of Flamingo proteins directs convergence and extension within the early zebrafish embryo via the planar cell polarity pathway. Dev Biol 282: 320-335.

Gao FB, Kohwi M, Brenman JE, Jan LY, Jan YN. 2000. Control of dendritic field formation in Drosophila: The roles of flamingo and competition between homologous neurons. Neuron 28: 91-101.

Gerdes JM, Liu Y, Zaghloul NA, Leitch CC, Lawson SS, Kato M, Beachy PA, Beales PL, DeMartino GN, Fisher S, et al. 2007. Disruption of the basal body compromises proteasomal function and perturbs intracellular Wnt response. Nat Genet 39: 1350-1360.

Goldstein B, Takeshita H, Mizumoto K, Sawa H. 2006. Wnt signals can function as positional cues in establishing cell polarity. Dev Cell 10: 391-396.

Gonczy P. 2008. Mechanisms of asymmetric cell division: Flies and worms pave the way. Nat Rev Mol Cell Biol 9: 355-366.

Gong Y, Mo C, Fraser SE. 2004. Planar cell polarity signalling controls cell division orientation during zebrafish gastrulation. Nature 430: 689-693.

Goodrich LV. 2008. The plane facts of PCP in the CNS. Neuron 60: 9-16.

Green JL, Inoue T, Sternberg PW. 2008. Opposing Wnt pathways orient cell polarity during organogenesis. Cell 134: $646-656$.

Gros J, Serralbo O, Marcelle C. 2008. WNT11 acts as a directional cue to organize the elongation of early muscle fibres. Nature 457: 589-593.

Gubb D, Green C, Huen D, Coulson D, Johnson G, Tree D, Collier S, Roote J. 1999. The balance between isoforms of the prickle LIM domain protein is critical for planar polarity in Drosophila imaginal discs. Genes Dev 13: 2315-2327.

Guo N, Hawkins C, Nathans J. 2004. Frizzled6 controls hair patterning in mice. Proc Natl Acad Sci 101: 9277-9281.

Habas R, Kato Y, He X. 2001. Wnt/Frizzled activation of Rho regulates vertebrate gastrulation and requires a novel Formin homology protein Daam1. Cell 107: 843-854.

He F, Xiong W, Yu X, Espinoza-Lewis R, Liu C, Gu S, Nishita M, Suzuki K, Yamada G, Minami Y, et al. 2008. Wnt5a regulates directional cell migration and cell proliferation via Ror2-mediated noncanonical pathway in mammalian palate development. Development 135: 3871-3879.

Heisenberg CP, Tada M, Rauch GJ, Saude L, Concha ML, Geisler R, Stemple DL, Smith JC, Wilson SW. 2000 Silberblick/Wnt11 mediates convergent extension movements during zebrafish gastrulation. Nature 405: 76-81.

Henderson DJ, Conway SJ, Greene ND, Gerrelli D, Murdoch JN, Anderson RH, Copp AJ. 2001. Cardiovascular defects associated with abnormalities in midline development in the Loop-tail mouse mutant. Circ Res 89: 6-12.

Hirokawa N, Tanaka Y, Okada Y. 2009. Left-Right determination: Involvement of molecular motor KIF3, cilia, and nodal flow. Cold Spring Harb Perspect Biol 1: a000802.
Hyodo-Miura J, Yamamoto TS, Hyodo AC, Iemura S, Kusakabe M, Nishida E, Natsume T, Ueno N. 2006. XGAP, an ArfGAP, is required for polarized localization of PAR proteins and cell polarity in Xenopus gastrulation. Dev Cell 11: 69-79.

Ishikawa HO, Takeuchi H, Haltiwanger RS, Irvine KD. 2008. Four-jointed is a Golgi kinase that phosphorylates a subset of cadherin domains. Science 321: 401-404.

Jenny A, Darken RS, Wilson PA, Mlodzik M. 2003. Prickle and Strabismus form a functional complex to generate a correct axis during planar cell polarity signaling. Embo J 22: 4409-4420.

Jenny A, Reynolds-Kenneally J, Das G, Burnett M, Mlodzik M. 2005. Diego and Prickle regulate Frizzled planar cell polarity signalling by competing for Dishevelled binding. Nat Cell Biol 7: 691-697.

Jessen JR. 2009. Noncanonical Wnt signaling in tumor progression and metastasis. Zebrafish 6: 21-28.

Jessen JR, Topczewski J, Bingham S, Sepich DS, Marlow F, Chandrasekhar A, Solnica-Krezel L. 2002. Zebrafish trilobite identifies new roles for Strabismus in gastrulation and neuronal movements. Nat Cell Biol 4: 610-615.

Jiang D, Munro EM, Smith WC. 2005. Ascidian prickle regulates both mediolateral and anterior-posterior cell polarity of notochord cells. Curr Biol 15: 79-85.

Jones C, Roper VC, Foucher I, Qian D, Banizs B, Petit C, Yoder BK, Chen P. 2008. Ciliary proteins link basal body polarization to planar cell polarity regulation. Nat Genet 40: 69-77.

Keller R. 2002. Shaping the vertebrate body plan by polarized embryonic cell movements. Science 298: 1950-1954.

Kelly M, Chen P. 2007. Shaping the mammalian auditory sensory organ by the planar cell polarity pathway. Int $J$ Dev Biol 51: 535-547.

Keys DN, Levine M, Harland RM, Wallingford JB. 2002. Control of intercalation is cell-autonomous in the notochord of Ciona intestinalis. Dev Biol 246: 329-340.

Kibar Z, Torban E, McDearmid JR, Reynolds A, Berghout J, Mathieu M, Kirillova I, De Marco P, Merello E, Hayes JM, et al. 2007. Mutations in VANGL1 associated with neuraltube defects. N Engl J Med 356: 1432-1437.

Kilian B, Mansukoski H, Barbosa FC, Ulrich F, Tada M, Heisenberg CP. 2003. The role of Ppt/Wnt5 in regulating cell shape and movement during zebrafish gastrulation. Mech Dev 120: 467-476.

Kimura H, Usui T, Tsubouchi A, Uemura T. 2006. Potential dual molecular interaction of the Drosophila 7-pass transmembrane cadherin Flamingo in dendritic morphogenesis. J Cell Sci 119: 1118-1129.

Klein TJ, Mlodzik M. 2005. Planar cell polarization: An emerging model points in the right direction. Annu Rev Cell Dev Biol 21: 155-176.

Klingensmith J, Noll E, Perrimon N. 1989. The segment polarity phenotype of Drosophila involves differential tendencies toward transformation and cell death. Developmental Biology 134: 130-145.

Kovar DR. 2006a. Cell polarity: Formin on the move. Curr Biol 16: 535-538.

Kovar DR. 2006b. Molecular details of formin-mediated actin assembly. Curr Opin Cell Biol 18: 11-17. 
Laumanns IP, Fink L, Wilhelm J, Wolff JC, Mitnacht-Kraus R, Graef-Hoechst S, Stein MM, Bohle RM, Klepetko W, Hoda MA, et al. 2009. The non-canonical WNT pathway is operative in idiopathic pulmonary arterial hypertension. Am J Respir Cell Mol Biol 40: 683-691.

Lawrence PA, Casal J, Struhl G. 2002. Towards a model of the organisation of planar polarity and pattern in the Drosophila abdomen. Development 129: 2749-2760.

Lawrence PA, Casal J, Struhl G. 2004. Cell interactions and planar polarity in the abdominal epidermis of Drosophila. Development 131: 4651-4664.

Lin F, Hiesberger T, Cordes K, Sinclair AM, Goldstein LS, Somlo S, Igarashi P. 2003. Kidney-specific inactivation of the KIF3A subunit of kinesin-II inhibits renal ciliogenesis and produces polycystic kidney disease. Proc Natl Acad Sci 100: 5286-5291.

Lu B, Usui T, Uemura T, Jan L, Jan YN. 1999. Flamingo controls the planar polarity of sensory bristles and asymmetric division of sensory organ precursors in Drosophila. Curr Biol 9: 1247-1250.

Lyuksyutova AI, Lu CC, Milanesio N, King LA, Guo N, Wang Y, Nathans J, Tessier-Lavigne M, Zou Y. 2003. Anterior-posterior guidance of commissural axons by Wnt-frizzled signaling. Science 302: 1984-1988.

Ma D, Yang CH, McNeill H, Simon MA, Axelrod JD. 2003. Fidelity in planar cell polarity signalling. Nature 421: 543-547.

Marszalek JR, Ruiz-Lozano P, Roberts E, Chien KR, Goldstein LS. 1999. Situs inversus and embryonic ciliary morphogenesis defects in mouse mutants lacking the KIF3A subunit of kinesin-II. Proc Natl Acad Sci 96: 5043-5048.

Matakatsu H, Blair SS. 2004. Interactions between Fat and Dachsous and the regulation of planar cell polarity in the Drosophila wing. Development 131: 3785-3794.

Matakatsu H, Blair SS. 2006. Separating the adhesive and signaling functions of the Fat and Dachsous protocadherins. Development 133: 2315-2324.

McCaffrey LM, Macara IG. 2009. Widely conserved signaling pathways in the establishment of cell polarity. Cold Spring Harb Perspect Biol 1: a001370.

McCarthy EK, Goldstein B. 2006. Asymmetric spindle positioning. Curr Opin Cell Biol 18: 79-85.

Mirkovic I, Mlodzik M. 2006. Cooperative activities of Drosophila DE-cadherin and DN-cadherin regulate the cell motility process of ommatidial rotation. Development 133: 3283-3293.

Mitchell B, Jacobs R, Li J, Chien S, Kintner C. 2007. A positive feedback mechanism governs the polarity and motion of motile cilia. Nature 447: 97-101.

Mizumoto K, Sawa H. 2007. Two $\beta$ s or not two $\beta$ s: Regulation of asymmetric division by $\beta$-catenin. Trends Cell Biol 17: 465-473.

Montcouquiol M, Sans N, Huss D, Kach J, Dickman JD, Forge A, Rachel RA, Copeland NG, Jenkins NA, Bogani D, et al. 2006. Asymmetric localization of Vangl2 and Fz3 indicate novel mechanisms for planar cell polarity in mammals. J Neurosci 26: 5265-5275.

Morgan D, Turnpenny L, Goodship J, Dai W, Majumder K, Matthews L, Gardner A, Schuster G, Vien L, Harrison W, et al. 1998. Inversin, a novel gene in the vertebrate left-right axis pathway, is partially deleted in the inv mouse. Nat Genet 20: 149-156.

Nachury MV, Loktev AV, Zhang Q, Westlake CJ, Peranen J, Merdes A, Slusarski DC, Scheller RH, Bazan JF, Sheffield VC, et al. 2007. A core complex of BBS proteins cooperates with the GTPase Rab8 to promote ciliary membrane biogenesis. Cell 129: 1201-1213.

Orlando K, Guo W. 2009. Membrane organization and dynamics in cell polarity. Cold Spring Harb Perspect Biol 1: a001321.

Otto EA, Schermer B, Obara T, O’Toole JF, Hiller KS, Mueller AM, Ruf RG, Hoefele J, Beekmann F, Landau D, et al. 2003. Mutations in INVS encoding inversin cause nephronophthisis type 2, linking renal cystic disease to the function of primary cilia and left-right axis determination. Nat Genet 34: 413-420.

Palamidessi A, Frittoli E, Garre M, Faretta M, Mione M, Testa I, Diaspro A, Lanzetti L, Scita G, Di Fiore PP. 2008. Endocytic trafficking of Rac is required for the spatial restriction of signaling in cell migration. Cell 134: 135-147.

Park TJ, Haigo SL, Wallingford JB. 2006. Ciliogenesis defects in embryos lacking inturned or fuzzy function are associated with failure of planar cell polarity and Hedgehog signaling. Nat Genet 38: 303-311.

Park WJ, Liu J, Sharp EJ, Adler PN. 1996. The Drosophila tissue polarity gene inturned acts cell autonomously and encodes a novel protein. Development 122: 961-969.

Park TJ, Mitchell BJ, Abitua PB, Kintner C, Wallingford JB. 2008. Dishevelled controls apical docking and planar polarization of basal bodies in ciliated epithelial cells. Nat Genet 40: 871-879.

Patel V, Li L, Cobo-Stark P, Shao X, Somlo S, Lin F, Igarashi P. 2008. Acute kidney injury and aberrant planar cell polarity induce cyst formation in mice lacking renal cilia. Hum Mol Genet 17: 1578-1590.

Qian D, Jones C, Rzadzinska A, Mark S, Zhang X, Steel KP, Dai X, Chen P. 2007. Wnt5a functions in planar cell polarity regulation in mice. Dev Biol 306: 121-133.

Roegiers F, Jan YN. 2004. Asymmetric cell division. Curr Opin Cell Biol 16: 195-205.

Roegiers F, Younger-Shepherd S, Jan LY, Jan YN. 2001. Two types of asymmetric divisions in the Drosophila sensory organ precursor cell lineage. Nat Cell Biol 3: 58-67.

Rohatgi R, Milenkovic L, Scott MP. 2007. Patched1 regulates hedgehog signaling at the primary cilium. Science 317 372-376.

Ross AJ, May-Simera H, Eichers ER, Kai M, Hill J, Jagger DJ, Leitch CC, Chapple JP, Munro PM, Fisher S, et al. 2005. Disruption of Bardet-Biedl syndrome ciliary proteins perturbs planar cell polarity in vertebrates. Nat Genet 37: 1135-1140.

Rosso SB, Sussman D, Wynshaw-Boris A, Salinas PC. 2005. Wnt signaling through Dishevelled, Rac and JNK regulates dendritic development. Nat Neurosci 8: $34-42$.

Saburi S, Hester I, Fischer E, Pontoglio M, Eremina V, Gessler M, Quaggin SE, Harrison R, Mount R, McNeill H. 2008. Loss of Fat 4 disrupts PCP signaling and oriented cell division and leads to cystic kidney disease. Nat Genet 40: $1010-1015$. 
E.K. Vladar, D. Antic, and J.D. Axelrod

Schambony A, Wedlich D. 2007. Wnt-5A/Ror2 regulate expression of XPAPC through an alternative noncanonical signaling pathway. Dev Cell 12: 779-792.

Schneider L, Clement CA, Teilmann SC, Pazour GJ, Hoffmann EK, Satir P, Christensen ST. 2005. PDGFR $\alpha \alpha$ signaling is regulated through the primary cilium in fibroblasts. Curr Biol 15: 1861-1866.

Sepich DS, Myers DC, Short R, Topczewski J, Marlow F, Solnica-Krezel L. 2000. Role of the zebrafish trilobite locus in gastrulation movements of convergence and extension. Genesis 27: 159-173.

Shima Y, Kengaku M, Hirano T, Takeichi M, Uemura T. 2004. Regulation of dendritic maintenance and growth by a mammalian 7-pass transmembrane cadherin. Dev Cell 7: 205-216.

Shimada Y, Usui T, Yanagawa S, Takeichi M, Uemura T. 2001. Asymmetric colocalization of Flamingo, a seven-pass transmembrane cadherin, and Dishevelled in planar cell polarization. Curr Biol 11: 859-863.

Shimada Y, Yonemura S, Ohkura H, Strutt D, Uemura T. 2006. Polarized transport of Frizzled along the planar microtubule arrays in Drosophila wing epithelium. Dev Cell 10: 209-222.

Shnitsar I, Borchers A. 2008. PTK7 recruits dsh to regulate neural crest migration. Development 135: 4015-4024.

Shulman JM, Perrimon N, Axelrod JD. 1998. Frizzled signaling and the developmental control of cell polarity. Trends Genet 14: 452-458.

Simon MA. 2004. Planar cell polarity in the Drosophila eye is directed by graded Four-jointed and Dachsous expression. Development 131: 6175-6184.

Simons M, Gloy J, Ganner A, Bullerkotte A, Bashkurov M, Kronig C, Schermer B, Benzing T, Cabello OA, Jenny A, et al. 2005. Inversin, the gene product mutated in nephronophthisis type II, functions as a molecular switch between Wnt signaling pathways. Nat Genet 37: 537-543.

Simons M, Mlodzik M. 2008. Planar cell polarity signaling: From fly development to human disease. Annu Rev Genet 42: $517-540$.

Simons M, Walz G. 2006. Polycystic kidney disease: Cell division without a c(1)ue? Kidney Int 70: 854-864.

Singla V, Reiter JF. 2006. The primary cilium as the cell's antenna: Signaling at a sensory organelle. Science 313: $629-633$.

Solnica-Krezel L. 2006. Gastrulation in zebrafish - all just about adhesion? Curr Opin Genet Dev 16: 433-441.

Strutt H, Strutt D. 2005. Long-range coordination of planar polarity in Drosophila. Bioessays 27: 1218-1227.

Strutt H, Strutt D. 2008. Differential stability of flamingo protein complexes underlies the establishment of planar polarity. Curr Biol 18: 1555-1564.

Strutt D, Warrington SJ. 2008. Planar polarity genes in the Drosophila wing regulate the localisation of the FH3-domain protein Multiple Wing Hairs to control the site of hair production. Development 135: 3103-3111.

Strutt DI, Weber U, Mlodzik M. 1997. The role of RhoA in tissue polarity and Frizzled signalling. Nature 387: 292-295.

Tada M, Smith JC. 2000. Xwnt11 is a target of Xenopus Brachyury: Regulation of gastrulation movements via
Dishevelled, but not through the canonical Wnt pathway. Development 127: 2227-2238.

Tahinci E, Symes K. 2003. Distinct functions of Rho and Rac are required for convergent extension during Xenopus gastrulation. Dev Biol 259: 318-335.

Tahirovic S, Bradke F. 2009. Neuronal polarity. Cold Spring Harb Perspect Biol 1: a001644.

Takeuchi M, Nakabayashi J, Sakaguchi T, Yamamoto TS, Takahashi H, Takeda H, Ueno N. 2003. The pricklerelated gene in vertebrates is essential for gastrulation cell movements. Curr Biol 13: 674-679.

Tanegashima K, Zhao H, Dawid IB. 2008. WGEF activates Rho in the Wnt-PCP pathway and controls convergent extension in Xenopus gastrulation. EMBO J 27: 606-617.

Taylor J, Abramova N, Charlton J, Adler PN. 1998. Van Gogh: A new Drosophila tissue polarity gene. Genetics 150: 199-210.

Theisen H, Purcell J, Bennett M, Kansagara D, Syed A Marsh JL. 1994. dishevelled is required during wingless signaling to establish both cell polarity and cell identity. Development 120: $347-360$.

Tissir F, Bar I, Jossin Y, De Backer O, Goffinet AM. 2005. Protocadherin Celsr3 is crucial in axonal tract development. Nat Neurosci 8: 451-457.

Tree DR, Ma D, Axelrod JD. 2002a. A three-tiered mechanism for regulation of planar cell polarity. Semin Cell Dev Biol 13: 217-224.

Tree DR, Shulman JM, Rousset R, Scott MP, Gubb D, Axelrod JD. 2002b. Prickle mediates feedback amplification to generate asymmetric planar cell polarity signaling. Cell 109: 371-381.

Ulrich F, Concha ML, Heid PJ, Voss E, Witzel S, Roehl H, Tada M, Wilson SW, Adams RJ, Soll DR, et al. 2003. $\mathrm{Slb} / \mathrm{Wnt} 11$ controls hypoblast cell migration and morphogenesis at the onset of zebrafish gastrulation. Development 130: 5375-5384.

Ulrich F, Krieg M, Schotz EM, Link V, Castanon I, Schnabel V, Taubenberger A, Mueller D, Puech PH, Heisenberg CP. 2005. Wnt11 functions in gastrulation by controlling cell cohesion through Rab5c and E-cadherin. Dev Cell 9: $555-564$.

Usui T, Shima Y, Shimada Y, Hirano S, Burgess RW, Schwarz TL, Takeichi M, Uemura T. 1999. Flamingo, a seven-pass transmembrane cadherin, regulates planar cell polarity under the control of Frizzled. Cell 98: 585-595.

Vavylonis D, Kovar DR, O'shaughnessy B, Pollard TD. 2006. Model of formin-associated actin filament elongation. Mol Cell 21: 455-466.

Veeman MT, Slusarski DC, Kaykas A, Louie SH, Moon RT. 2003. Zebrafish prickle, a modulator of noncanonical $\mathrm{Wnt} / \mathrm{Fz}$ signaling, regulates gastrulation movements. Curr Biol 13: 680-685.

Vervenne HB, Crombez KR, Lambaerts K, Carvalho L, Koppen M, Heisenberg CP, Van de Ven WJ, Petit MM. 2008. Lpp is involved in Wnt/PCP signaling and acts together with Scrib to mediate convergence and extension movements during zebrafish gastrulation. Dev Biol 320: $267-277$.

Vinson CR, Conover S, Adler PN. 1989. A Drosophila tissue polarity locus encodes a protein containing seven potential transmembrane domains. Nature 338: 263-264. 
Wada H, Tanaka H, Nakayama S, Iwasaki M, Okamoto H. 2006. Frizzled $3 \mathrm{a}$ and Celsr2 function in the neuroepithelium to regulate migration of facial motor neurons in the developing zebrafish hindbrain. Development 133: 4749-4759.

Wallar BJ, Alberts AS. 2003. The formins: Active scaffolds that remodel the cytoskeleton. Trends Cell Biol 13: $435-446$.

Wallingford JB. 2006. Planar cell polarity, ciliogenesis and neural tube defects. Hum Mol Genet 15 Spec No 2: R227-234.

Wallingford JB, Harland RM. 2001. Xenopus Dishevelled signaling regulates both neural and mesodermal convergent extension: Parallel forces elongating the body axis. Development 128: 2581-2592.

Wallingford JB, Harland RM. 2002. Neural tube closure requires Dishevelled-dependent convergent extension of the midline. Development 129: 5815-5825.

Wallingford JB, Vogeli KM, Harland RM. 2001. Regulation of convergent extension in Xenopus by Wnt5a and Frizzled-8 is independent of the canonical Wnt pathway. Int J Dev Biol 45: 225-227.

Wallingford JB, Fraser SE, Harland RM. 2002. Convergent extension: The molecular control of polarized cell movement during embryonic development. Dev Cell 2: 695-706.

Wallingford JB, Rowning BA, Vogeli KM, Rothbacher U, Fraser SE, Harland RM. 2000. Dishevelled controls cell polarity during Xenopus gastrulation. Nature 405: 81-85.

Wang Y, Nathans J. 2007. Tissue/planar cell polarity in vertebrates: New insights and new questions. Development 134: 647-658.

Wang Y, Guo N, Nathans J. 2006b. The role of Frizzled3 and Frizzled6 in neural tube closure and in the planar polarity of inner-ear sensory hair cells. J Neurosci 26: 2147-2156.

Wang Y, Zhang J, Mori S, Nathans J. 2006c. Axonal growth and guidance defects in Frizzled3 knock-out mice: A comparison of diffusion tensor magnetic resonance imaging, neurofilament staining, and genetically directed cell labeling. J Neurosci 26: 355-364.

Wang J, Hamblet NS, Mark S, Dickinson ME, Brinkman BC, Segil N, Fraser SE, Chen P, Wallingford JB, Wynshaw-Boris A. 2006a. Dishevelled genes mediate a conserved mammalian PCP pathway to regulate convergent extension during neurulation. Development 133: 1767-1778.

Wang J, Mark S, Zhang X, Qian D, Yoo SJ, Radde-Gallwitz K, Zhang Y, Lin X, Collazo A, Wynshaw-Boris A, et al. 2005. Regulation of polarized extension and planar cell polarity in the cochlea by the vertebrate PCP pathway. Nat Genet 37: 980-985.

Wang Y, Thekdi N, Smallwood PM, Macke JP, Nathans J. 2002. Frizzled-3 is required for the development of major fiber tracts in the rostral CNS. J Neurosci 22: 8563-8573.

Wehrli M, Tomlinson A. 1998. Independent regulation of anterior/posterior and equatorial/polar polarity in the Drosophila eye; evidence for the involvement of Wnt signaling in the equatorial/polar axis. Development 125: $1421-1432$.
Winklbauer R, Medina A, Swain RK, Steinbeisser H. 2001 Frizzled-7 signalling controls tissue separation during Xenopus gastrulation. Nature 413: 856-860.

Winter CG, Wang B, Ballew A, Royou A, Karess R, Axelrod JD, Luo L. 2001. Drosophila Rho-associated kinase (Drok) links Frizzled-mediated planar cell polarity signaling to the actin cytoskeleton. Cell 105: 81-91.

Witzel S, Zimyanin V, Carreira-Barbosa F, Tada M, Heisenberg CP. 2006. Wnt11 controls cell contact persistence by local accumulation of Frizzled 7 at the plasma membrane. J Cell Biol 175: 791-802.

Wolf AM, Lyuksyutova AI, Fenstermaker AG, Shafer B, Lo CG, Zou Y. 2008. Phosphatidylinositol-3-kinase-atypical protein kinase $\mathrm{C}$ signaling is required for Wnt attraction and anterior-posterior axon guidance. J Neurosci 28: 3456-3467.

Wolff T, Rubin GM. 1998. Strabismus, a novel gene that regulates tissue polarity and cell fate decisions in Drosophila. Development 125: 1149-1159.

Wong LL, Adler PN. 1993. Tissue polarity genes of Drosophila regulate the subcellular location for prehair initiation in pupal wing hairs. Journal of Cell Biology 123: $209-221$.

Wu M, Herman MA. 2006. A novel noncanonical Wnt pathway is involved in the regulation of the asymmetric B cell division in C. elegans. Dev Biol 293: 316-329.

Yang CH, Axelrod JD, Simon MA. 2002. Regulation of Frizzled by fat-like cadherins during planar polarity signaling in the Drosophila compound eye. Cell 108: 675-688.

Ybot-Gonzalez P, Savery D, Gerrelli D, Signore M, Mitchell CE, Faux CH, Greene ND, Copp AJ. 2007. Convergent extension, planar-cell-polarity signalling and initiation of mouse neural tube closure. Development 134: 789-799.

Yin C, Kiskowski M, Pouille PA, Farge E, Solnica-Krezel L. 2008. Cooperation of polarized cell intercalations drives convergence and extension of presomitic mesoderm during zebrafish gastrulation. J Cell Biol 180: 221-232.

Zallen JA. 2007. Planar polarity and tissue morphogenesis. Cell 129: 1051-1063.

Zech T, Machesky L. 2008. Rab5 and rac team up in cell motility. Cell 134: 18-20.

Zeidler MP, Perrimon N, Strutt DI. 1999. The four-jointed gene is required in the Drosophila eye for ommatidial polarity specification. Curr Biol 9: 1363-1372.

Zeidler MP, Perrimon N, Strutt DI. 2000. Multiple roles for four-jointed in planar polarity and limb patterning. Dev Biol 228: 181-196.

Zhang X, Zhu J, Yang GY, Wang QJ, Qian L, Chen YM, Chen F, Tao Y, Hu HS, Wang T, et al. 2007. Dishevelled promotes axon differentiation by regulating atypical protein kinase C. Nat Cell Biol 9: 743-754.

Zhu S, Liu L, Korzh V, Gong Z, Low BC. 2006. RhoA acts downstream of Wnt5 and Wnt11 to regulate convergence and extension movements by involving effectors Rho kinase and Diaphanous: Use of zebrafish as an in vivo model for GTPase signaling. Cell Signal 18: 359-372. 


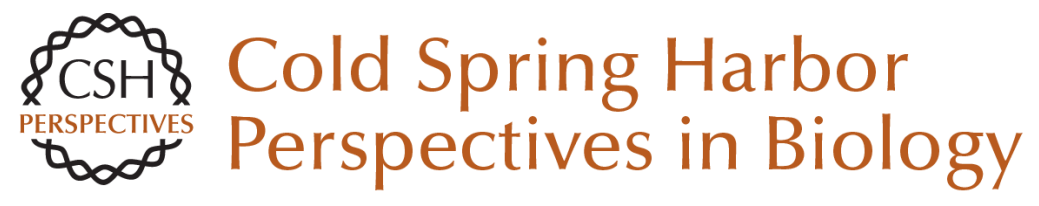

\title{
Planar Cell Polarity Signaling: The Developing Cell's Compass
}

\author{
Eszter K. Vladar, Dragana Antic and Jeffrey D. Axelrod
}

Cold Spring Harb Perspect Biol 2009; doi: 10.1101/cshperspect.a002964 originally published online August 12, 2009

Subject Collection Symmetry Breaking in Biology

Cytoskeletal Mechanisms for Breaking Cellular Symmetry

R. Dyche Mullins

\section{Symmetry Breaking in Biology}

Rong Li and Bruce Bowerman

Planar Cell Polarity Signaling: The Developing

\section{Cell's Compass}

Eszter K. Vladar, Dragana Antic and Jeffrey D. Axelrod

Cellular Polarity in Prokaryotic Organisms Jonathan Dworkin

Symmetry Breaking in Plants: Molecular Mechanisms Regulating Asymmetric Cell

Divisions in Arabidopsis Jalean J. Petricka, Jaimie M. Van Norman and Philip N. Benfey

The Signaling Mechanisms Underlying Cell

Polarity and Chemotaxis Fei Wang

Polarization of Drosophila Neuroblasts During Asymmetric Division Kenneth E. Prehoda

Physical Model of Cellular Symmetry Breaking Jasper van der Gucht and Cécile Sykes
Polarity in Stem Cell Division: Asymmetric Stem Cell Division in Tissue Homeostasis

Yukiko M. Yamashita, Hebao Yuan, Jun Cheng, et al.

Symmetry Breaking in the Life Cycle of the Budding Yeast

Brian D. Slaughter, Sarah E. Smith and Rong Li

Neuronal Polarity

Sabina Tahirovic and Frank Bradke

Membrane Organization and Dynamics in Cell

Polarity Kelly Orlando and Wei Guo

Cellular Symmetry Breaking during Caenorhabditis elegans Development Edwin Munro and Bruce Bowerman

Symmetry Breaking During Drosophila Oogenesis Siegfried Roth and Jeremy A. Lynch

Widely Conserved Signaling Pathways in the Establishment of Cell Polarity Luke Martin McCaffrey and lan G. Macara

Shaping Fission Yeast with Microtubules Fred Chang and Sophie G. Martin

For additional articles in this collection, see http://cshperspectives.cshlp.org/cgi/collection/

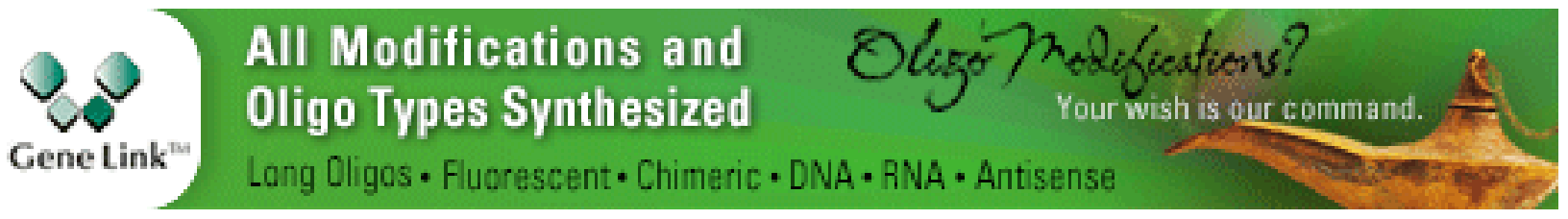

